\title{
Penentu Penyebab Kematian di RSUD Panembahan Senopati Bantul: Miscoding Berdampak pada Laporan Statistik Kematian
}

\author{
Laili Rahmatul Ilmi' ${ }^{1}$, Zakharias Purbobinuko \\ ${ }^{1,2}$ Universitas Jenderal Achmad Yani dan Jl. Brawijaya, Ring Road Barat, \\ Ambarketawang, Gamping, Sleman, Yogyakarta \\ Email: lailiilmi@gmail.com
}

\begin{abstract}
The doctor's explanation of the cause of death form contains the sequence of the disease that caused the patient to die. The determination of the underlying cause of death (UCOD) has been standardized by the WHO. The right UCOD supports decision-makers and health policy, but much of the information is inaccurate, thus affecting death reports. This study aims to measure the quality of UCOD and miscoding in Panembahan Senopati Bantul District Hospital. This research is descriptive. Retrieval of data using observation checklist, interviews and study of medical records of patients and death certificates for the 2018 period were 120 sheets. The results of the UCOD quality analysis are not possible 46 (38\%), improper UCOD 39 (33\%), there are multiple unrelated conditions reported in one row 15 (13\%), there is one condition that is reported as 12 (10\%) and UCOD is not specific 8 (7\%). A total of 55 diagnoses were reported as UCOD. The highest classification of diagnoses was in the Certain infectious and parasitic diseases group 10 (18\%), the Sign group, symptoms, Abnormal Finding were 9 (16\%) and the Diseases of the circulatory system group $8(15 \%) .374$ diagnoses reported in the letter meet the exact coding category (55) and incorrect (311). The results of the interview with the UCOD determination coder are not according to WHO, due to the lack of understanding of the rule and UCOD determination so that it can affect the quality of death reports.
\end{abstract}

Keywords: miscoding, UCOD, Death Certificate, Death Report

\begin{abstract}
Abstrak
Formulir keterangan penyebab kematian dibuat dokter berisikan runtutan penyakit penyebab pasien meninggal. Penentuan underlying cause of death (UCOD) telah distandarkan oleh WHO. UCOD yang tepat mendukung pengambil keputusan dan kebijakan kesehatan, namun informasi tersebut banyak yang tidak akurat sehingga berpengaruh pada laporan kematian. Penelitian ini bertujuan mengukur kualitas UCOD dan miscoding di RSUD Panembahan Senopati Bantul. Penelitian ini merupakan penelitian deskriptif. Pengambilan data menggunakan checklist observasi, wawancara dan studi dokumen rekam medis pasien dan surat keterangan kematian periode 2018 sebanyak 120 lembar. Hasil analisis kualitas UCOD runtutannya tidak mungkin 46(38\%), UCOD tidak tepat 39 (33\%), terdapat multiple kondisi yang tidak berkaitan dilaporkan dalam satu baris 15(13\%), terdapat satu kondisi yang dilaporkan sebesar 12(10\%) dan UCOD tidak spesifik 8(7\%). Sebanyak 55 diagnosis yang dilaporkan sebagai UCOD. Penggolongan diagnosis tertinggi pada kelompok Certain infectious and parasitic diseases 10(18\%), kelompok Sign, symtoms, Abnormal Finding sebanyak 9(16\%) dan kelompok Diseases of the circulatory system 8(15\%). 374 dignosis dilaporkan dalam surat tersebut memenuhi kategori coding tepat (55) dan tidak tepat (311). Hasil wawancara dengan coder penentuan UCOD belum sesuai WHO, disebabkan minimnya pemahaman penentuan rule dan UCOD sehingga dapat berpengaruh pada kualitas laporan kematian.
\end{abstract}

Kata kunci:miscoding, UCOD, Surat Keterangan Kematian, Laporan Kematian 


\section{PENDAHULUAN}

Setiap fasilitas kesehatan wajib membuat sertifikat kematian yang dilaporkan kepada pihak eksternal antara lain Dinas Kesehatan Kabupaten Kota, provinsi, ataupun pihak penyedia jaminan kesehatan, pihak asuransi dan lainnya. Ketepatan pemilihan code penyebab kematian pada sertifikat kematian memiliki peranan penting, karena data tersebut digunakan sebagai dasar untuk melakukan seleksi aturan dalam mementukan penyebab dasar kematian. (Jansson, 2005).

Laporan penyebab kematian dapat digunakan sebagai bahan untuk melakukan monitoring terhadap status kesehatan secara umum, serta untuk pencegahan penyakit yang menjadi penyebab kematian (Walker, 2012). Pada pembuatan sertifikat kematian melalui beberapa tahapan, dimulai dari penulisan diagnosis oleh dokter yang merawat pasien kedalam sertifikat kematian, selanjutnya sertifikat tersebut dikde oleh petugas yang diberikan wewenang. Keakuratan pemberian kode penyebab kematian berpengaruh terhadap ketepatan pemilihan penyebab utama kematian (Underlying Cause Of Death) yang dilaporkan dalam statistik mortalitas (John Hopkins, 2006). Penyebab kematian tersebut oleh WHO (World Health Organization) tertuang dalam ICD10 (International Classification Diagnostic And Statistical $10^{\text {th }}$ Revision) dapat digunakan dalam pendukung keputusan untuk menurunkan angka morbiditas dan mortalitas.

Data statistik kematian yang dilaporkan melalui pencatatan dan pelaporan rutin oleh rumah sakit di diy melalui mekanisme sirs penyebab kematian yang dilaporkan disebabkan oleh 5 besar penyakit, diantaranya septicaemia (150 kasus), pendarahan intrakanial (130 kasus), infark cerebral (120 kasus), kecelakaan lalu lintas (120 kasus), gagal jantung (110 kasus) data yang dlaporkan tersebut menunjukkan bahwa penyebab kematian di Yogyakarta didominasi oleh penyakit-penyakit tidak menular. Septisima adalah penyebab kematian paling tinggi, sedangkan urutan ke-5 penyebab kematian di DI. Yogyakarta adalah gagal jantung(Dinkes Yogyakarta, 2016).

Pada sertifikat kematian dokter menuliskan beberapa diagnosis atau kondisi yang menjadi dasar pasien meninggal, selanjutnya diagnosis tersebut diseleksi menggunkan aturan (rule) yang telah terstandarisasi dan sesuai kaidah aturan internasional (ICD-10). Seorang tenaga coding (coder) harus memberikan kode diagnosis yang tepat pada surat kematian untuk menentukan underlying cause of death(Scott et al., 2005).

Beberapa penelitan sebelumnya menjelaskan bahwa ketepatan code diagnosis tidak hanya menggambarkan mutu rekam medis melainkan kode yang tepat berdampak terhadap survailans, data statistik, dasar sebuah penelitian, pembiayaan kesehatan (Hersh, 2016). Meskipun diagnosis pada sertifikat kematian terdiri lebih dari satu diagnosis, namun masih terdapat coder yang belum memberikan kode yang tepat, sehingga pemilihan $\mathrm{UCoD}$ bisa tidak tepat.(Lu, Lee and Chou, 2000)

Coding pada sertifikat kematian digunakan sebagai bahan untuk menghimpun informulirasi penyebab meninggalnya seseorang berdasarkan penyakit dan mencari solusi yang tepat dengan menggunakan sistem untuk melakukan seleksi UCoD pada diagnosis yang dtegakkan oleh dokter (IFHIMA, 2012)

Code yang tepat memiliki peranan penting dalam mencapai tujuan statistic kesehatan. salah satu alternatif yang masih belum banyak diteliti adalah pengaruh ketepatan coding diagnosis untuk menentukan underlying cause of death berdampak kepada statistik mortalitas.

\section{METODE}

Metode penelitian ini merupakan penelitian deskriptif dengan mix method melalui studi kasus dengan strategi eksplanatori sekuensial. Populasi objek pada penelitian ini adalah berkas rekam medis dan surat keterangan kematian sebanyak 684 surat kemaitian dalam rekam medis pasien meninggal selama periode Januari sampai dengan Desember 2019. Sampel surat keterangan kematian yang diteliti dengan cara pengambilan sampel secara acak sebanyak 120 surat keterangan. Pengambilan datanya menggunakan checklist ketepatan dalam penentuan UCOD dan menggunakan tabel MMDS untuk mengukur kualitas coding dalam menentukan UCOD. Uji analisis ketepatan pemilihan UCOD penyebab kematian dengan uji chi-square. Hasil uji disajikan dalam bentuk narasi deksriptif

\section{HASIL}

\section{Studi Populasi}

Pada Tahun 2018 terdapat sebanyak 684 surat kematian yang dibuat oleh RSUD Panembahan 
Senopati Bantul Yogyakarta, peneliti mengambil secara random sampling sebanyak 120 surat keterangan kematian yang dibuat periode Januari sampai dengan Desember tahun 2018. Dari 120 surat keterangan kematian yang dilampirkan dalam rekam medis pasien peneliti menjabarkan karakteristik pasien berdasarkan jenis kelamin, umur dan pekerjaan (tabel 1). Sebagian besar pasien meninggal berjenis kelamin laki-laki berjumlah 73 $(60,83 \%)$ dengan pengelompokkan usia terbesar (6180 tahun) sebesar 53\% dengan pekerjaan sebagai ibu rumah tangga 31 (26\%). Surat keterangan kematian dibuat oleh dokter berdasarkan kasus diagnosis penyebab kematian, hasil investigasi dan informasi patologis pasien untuk dapat menentukan penyebab kematian (COD). Peneliti membuka rekam medis satu per satu untuk mendapatkan informasi secara lengkap terkait penyebab dasar kematian atau UCOD (Underlying Cause of Death), melihat diagnosis utama, diagnosis sekunder, lamanya perawatan, kondisi kematian apakah terjadi di luar rumah sakit atau saat perawatan, serta resume medis pasien dan tentunya laporan kematian.

Tabel 1. Distribusi Frekuensi Data Administratif

\begin{tabular}{lcc}
\hline \multicolumn{1}{c}{ Item } & jumlah & Frekuensi (\%) \\
\hline Jenis Kelamin & & \\
Laki -laki & 73 & 60.83 \\
Perempuan & 47 & 39.17 \\
Umur & & \\
=<5 tahun & 2 & 2 \\
6-20 & 5 & 4 \\
21-40 & 20 & 17 \\
41-60 & 63 & 53 \\
61- 80 & 28 & 23 \\
$>80$ & 2 & 2 \\
tidak sekolah & 1 & 1 \\
Pelajar & 8 & 7 \\
Buruh & 14 & 12 \\
Ibu rumah tangga & 31 & 26 \\
PNS & 9 & 8 \\
Swasta & 29 & 24 \\
Wiraswasta & 22 & 12 \\
Pensiunan & 6 & 5 \\
\hline
\end{tabular}

Dari tabel diatas (Tabel 1) untuk karakteristik jenis kelamin pasien meninggal terbesar dialami oleh laki-laki 73 (60.83\%),perempuan 47(39.17\%) usia tertua diatas 80 tahun dan termuda 2 tahun, dengan distribusi pekerjaan tertinggi sebagai ibur rumah tangga $31(26 \%)$ dan terendah tidak sekolah (1\%).

\section{Kualitas UCOD}

Peneliti melakukan pengukuran kualitas UCOD dengan mengklasifikasikan menjadi 5 bagian secara umum dengan cara memilih surat keterangan kematian yang diisikan oleh dokter diantaranya: UCOD tidak tepat, Pemilihan UCOD yang tidak spesifik, terdapat multiple kondisi yang tidak berkaitan dilaporkan dalam satu baris, UCOD tidak spesifik dan terdapat satu kondisi yang dilaporkan saja (Tabel 2).

Penggolongan UCOD tersebut mengacu pada standarisasi yang dtetatpkan oleh WHO bahwa untuk menentukan UCOD dalam surat keteranga kematian melalui beberapa tahapan dan reseleksi dalam memilih diagnosis penyebab kematian. Penelitia menelusur penentuan UCOD yang dilaporkan dalam surat kematian dengan melihat formulir ringkasan masuk dan keluar pada lember kedua, membaca resume medis, mencocokkan surat kematian dan laporan kematian. Pada lembar ringkasan masuk keluar dilakukan pengecekan kode diagnosis yang diisikan oleh coder menggunakan ICD-10 volum 1 dan 3, selanjutnya UCOD yang dipilih pada surat keterangan kematian dinilai kualitasnya dengan menggunakan checklist pengukuran kualitas UCOD dan telusur kembali dengan tabel MMDS.

Hasil pengukuran kualitas UCOD yang dilaporkan, peneliti mengklasifikasikan UCOD menjadi 5 bagian (Tabel 3). Dari tabel 3 diketahui bahwa pada peruntutan kasus yang tidak mungkin sebesar 46 (38\%), UCOD tidak tepat 39 (33\%), Terdapat multiple kondisi yang tidak berkaitan dilaporkan dalam satubaris $15(13 \%)$, terdapat satu kondisi yang dilaporkan saja sebesar $12(10 \%)$.

Untuk pengukuran hubungan antara kualitas UCOD dengan diagnosis yang dilaporkan, peneliti menggolongkan diagnosis mengacu ICD-10 yang dilaporkan (Tabel 4). Dari 120 surat keterangan kematian yang dibuat periode tahuan 2018, diperoleh digaoisis yang telah dikelompokkan sebanyak 55 diagnosis yang sebagai penyebab dasar kematian (UCOD). Penggolongan diagnosis tertinggi sebagai UCOD, pada kelompok Certain infectious and parasitic diseases sebanyak 10 diagnosis (18\%), penggolongan berdasarkan Sign, symtoms, Abnormal Finding sebanyak 9 diagnosis (16\%) dan kelompok Diseases of the circulatory system sebesar 8 (15\%).

Selanjutnya surat kematian sebanyak 120 lembar terebut, dianalisis kembali untuk menilai ketepatan pemberian coding diagnosis oleh coder dan UCOD 
yang dipilih, selanjutnya dicocokkan kembali dengan laporan kematian pada tahun 2018 (Tabel 5) diketahui bahwa dari 120 surat kematian, diagnosis yan dilaporkan sebagai laporan kematian sebanyak 374 kasus sebagai penyebab dasar kematian, dari diagnosis yang dilaporkan tertinggi adalah diagnosis pada kelompok infeksi dengan kasus sepsis 48

Tabel 2. Klasifikasi pengukuran kualitas UCOD

\begin{tabular}{|c|c|c|c|}
\hline & Definisi & Spesifikasi & Contoh kesalahan eror \\
\hline UCOD tidak tepat & $\begin{array}{l}\text { UCOD dipilih menggunakan } \\
\text { standar internasional, namun } \\
\text { terdapat kondisi yang diisikan } \\
\text { dokter tidak berhubungan }\end{array}$ & $\begin{array}{l}\text { Kondisi yang dilaporkan dalam } \\
\text { sertifikat kematian pada baris } \\
\text { bawah bagian I dipilih sebagai } \\
\text { UCOD, namun ada kondisi } \\
\text { lain yang dilaporkan dengan } \\
\text { menggunakan rule sesuai standar } \\
\text { nasional }\end{array}$ & $\begin{array}{l}\text { UCOD dipilih dari } \\
\text { kondisi pada bagian II } \\
\text { pada surat keterangan } \\
\text { kematian } \\
\text { Bagian I "Sepsis" due to } \\
\text { "Pneumonia" } \\
\text { Bagian II "HIV" }\end{array}$ \\
\hline UCOD yang tidak spesifik & $\begin{array}{l}\text { Pemilihan kondisi anataomi } \\
\text { atau kondisi pisikologi yang } \\
\text { dilaporkans seperti "Sepsis", } \\
\text { Acute Myocadial Infraction, } \\
\text { dan Pneumonia" dipilih sebagai } \\
\text { UCOD pada baris terakhir pada } \\
\text { bagian I }\end{array}$ & $\begin{array}{l}\text { Kondisi yang diisikan oleh dokter } \\
\text { untuk kasus yang tidak spesifik } \\
\text { pada baris paling bawah pada } \\
\text { bagian I }\end{array}$ & $\begin{array}{l}\text { "septic shock" due to } \\
\text { "bilateral lower lobe } \\
\text { pneumonia" }\end{array}$ \\
\hline $\begin{array}{l}\text { terdapat multiple kondisi } \\
\text { yang tidak berkaitan } \\
\text { dilaporkan dalam satu baris }\end{array}$ & $\begin{array}{l}\text { Multiple kondisi yang dilaporkan } \\
\text { pada satu baris pada bagian I atau } \\
\text { ada perbedaan BAB ICD-10 }\end{array}$ & $\begin{array}{l}\text { Kecuali kondisi yang dilaporkan } \\
\text { memiliki persamaan BAB dalam } \\
\text { ICD-10 }\end{array}$ & $\begin{array}{l}\text { Hypertention dan } \\
\text { Diabetes Milletus pada } \\
\text { bagian I }\end{array}$ \\
\hline $\begin{array}{l}\text { Rangkaian kondisi yang } \\
\text { tidak masuk akal }\end{array}$ & $\begin{array}{l}\text { Terdapat hubungan kausal yang } \\
\text { tidak dilaporkan }\end{array}$ & $\begin{array}{l}\text { Termasuk kondisi sekuesial yang } \\
\text { tidak dilaporkan menjadi kondisi } \\
\text { spesifik }\end{array}$ & $\begin{array}{l}\text { "coronary artery } \\
\text { disease" due to breast } \\
\text { cancer }\end{array}$ \\
\hline $\begin{array}{l}\text { terdapat satu kondisi yang } \\
\text { dilaporkan saja }\end{array}$ & $\begin{array}{l}\text { Hanya terdapat } 1 \text { kondisi yang } \\
\text { dilaporkan pada bagian I dan II }\end{array}$ & $\begin{array}{l}\text { Yang tidak termasuk kondisi pada } \\
\text { bagian II, termasuk juga kondisi } \\
\text { metastase, stadium penyakit }\end{array}$ & "uterine cancer" \\
\hline
\end{tabular}

Tabel 3. Tabel pengukuran kualitas UCoD pada surat keterangan kematian tahun 2018

\begin{tabular}{lcc}
\hline \multicolumn{1}{c}{ Kualitas UCOD } & Jumlah & \% \\
\hline sertifikat kematian & $\mathbf{1 2 0}$ & $\mathbf{1 0 0}$ \\
UCOD tidak tepat & 39 & 33 \\
Peruntutan kasus yang tidak mungkin & 46 & 38 \\
Terdapat multiple kondisi yang tidak & 15 & 13 \\
berkaitan dilaporkan dalam satu baris & & \\
UCOD tidak spesifik & 8 & 7 \\
Terdapat satu kondisi yang dilaporkan & 12 & 10 \\
\hline
\end{tabular}

Tabel 4. Pengelompokan Diagnosis berdasarkan ICD-10 dalam surat keterangan kematian 2018

\begin{tabular}{cccc}
\hline No & Kelompok Diagnosis & Jumlah & $\%$ \\
\hline 1 & $\begin{array}{l}\text { A00-B99 Certain infectious } \\
\text { and parasitic diseases }\end{array}$ & 10 & 18 \\
2 & $\begin{array}{l}\text { C00-D49 Neoplasms } \\
\text { C0 }\end{array}$
\end{tabular}

dengan tingkat ketepatan (11) tidak tepat (43), urutan kedua pada kelompok penyakit pada sistem saluran pembuluh darah dengan kasus stroke sebesar 36 dengan tingkat ketepatan (10) tidka tepat (26), dan urutan ketiga yaitu pada kelompok penyakit sistem pernafasan dengan kasus pneumonia 17 dengan tingkat ketepatan (1) dan tidak tepat (16). metastase, stadium penyakit
3 D50-D89 Diseases of the blood and blood-forming organs / certain disorders involving the immune mechanism

4 E00-E89 Endocrine, nutritional and metabolic diseases

5 I00-I99 Diseases of the circulatory system respiratory system

7 K00-K95 Diseases of the $3 \quad 5$ digestive system

8 M00-M99 Diseases of the 112 musculoskeletal system

9 N00-N99 Diseases of the $3 \quad 5$ genitourinary system

10 O00-O99 Pregnancy, Materal $\quad 1 \quad 2$ Condition and Post partum condition
6 J00-J99 Diseases of the 
Laili Rahmatul Ilmi dan Zakharias Purbobinuko. Penentu Penyebab Kematian di RSUD Panembahan ...

11 P00-P96 Certain conditions originating in the perinatal period

12 Q00-Q99 Congenital malformations, deformations and chromosomal abnormalities

13 Sign, symtoms, Abnormal $9 \quad 16$ Finding total diagnosis

$55 \quad 10$

Tabel 5. Ketepatan pemilihan UCOD di RSUD Panembahan Senopati

\begin{tabular}{lccc}
\hline \multicolumn{1}{c}{ Cuase of Death } & N & Frekuensi \\
\hline \multicolumn{1}{c}{ UCOD } & 374 & Tepat & $\begin{array}{r}\text { Tidak } \\
\text { Tepat }\end{array}$ \\
\hline Ch a p 1 : A 0 0-B 99 & C e r t a i n & & \\
infectious and parasitic diseases & & & \\
Sepsis & 48 & 11 & 37 \\
HIV & 12 & 0 & 12 \\
bacterial infection & 16 & 1 & 15 \\
leptospirosis & 1 & 0 & 1 \\
Tuberculosis & 8 & 2 & 6 \\
\hline Chapt2:C00-D49 Neoplasms & & & \\
Carcinoma Nasopharingitis & 3 & 0 & 3 \\
carcinoma mammae & 4 & 0 & 4 \\
Tumor mesenterium & 1 & 0 & 1 \\
\hline
\end{tabular}

Chapter 3:D50-D89 Diseases of the blood and blood-forming organs / certain disorders involving the immune mechanism

$\begin{array}{llll}\text { anemia } & 8 & 2 & 6 \\ \text { Aplastic anemia } & 1 & 0 & 1 \\ \text { Iron deficiency } & 2 & 0 & 2 \\ \text { thalasemia } & 2 & 0 & 2 \\ \text { trombhocitophenya } & 1 & 0 & 1\end{array}$

Chapter 4:E00-E89 Endocrine, nutritional and metabolic diseases

\begin{tabular}{lccc} 
DM & 13 & 2 & 11 \\
IDDM & 3 & 0 & 3 \\
NIDDM & 2 & 1 & 1 \\
Hypoparathyroidism & 1 & 0 & 1 \\
\hline
\end{tabular}

Chapter 5: F01-F99 Mental, Behavioral and Neurodevelopmental disorders

$\begin{array}{llll}\text { alcoholic } & 1 & 0 & 1\end{array}$

Chapter 6: G00-G99 Diseases of the nervous system

\begin{tabular}{llll} 
Meningitis & 4 & 0 & 3 \\
Encephaltis & 3 & 1 & 2 \\
polyneuropathy & 1 & 0 & 1 \\
\hline
\end{tabular}

\begin{tabular}{lccc}
\hline $\begin{array}{l}\text { Chapter 7: H00-H99 Disease of } \\
\text { eye, skin, adnexa }\end{array}$ & & & \\
Cataract senile & 2 & 0 & 1 \\
Glaucoma & 1 & 0 & 1 \\
\hline $\begin{array}{l}\text { Chapter 9: I00-I99 Diseases of the } \\
\text { circulatory system }\end{array}$ & & & \\
HHD & 3 & 0 & 3 \\
Hypertention & 10 & 2 & 8 \\
ICH & 4 & 0 & 4 \\
IHD & 5 & 1 & 4 \\
hypertention & 6 & 2 & 4 \\
SNH & 8 & 3 & 5 \\
atrial fbrilation & 3 & 1 & 2 \\
intraventricular hemorrhage & 5 & 3 & 2 \\
Stroke & 36 & 10 & 26 \\
\hline
\end{tabular}

Chapter 10: J00-J99 Diseases of the respiratory system

$\begin{array}{lccc}\text { Bronchopneumonia } & 6 & 0 & 6 \\ \text { ISPA } & 6 & 1 & 5 \\ \text { emphysema } & 3 & 2 & 1 \\ \text { pneumonia } & 24 & 1 & 23\end{array}$

Chapter 11: K00-K95 Diseases of the digestive system

$\begin{array}{llll}\text { Appendixitis } & 7 & 1 & 6\end{array}$

$\begin{array}{llll}\text { cholecystis } & 2 & 1 & 1\end{array}$

$\begin{array}{llll}\text { Alcoholic liver disease } & 3 & 1 & 2\end{array}$

$\begin{array}{llll}\text { Inguinal hernia } & 3 & 1 & 2\end{array}$

Chapter 12: L00-L99 Diseases of the skin and subcutaneous tissue

$\begin{array}{llll}\text { ulcer } & 1 & 1 & 0\end{array}$

Chapter 13: M00-M99 Diseases of the musculoskeletal system / connective tissue

$\begin{array}{llll}\text { Rheumatoid arthritis } & 2 & 1 & 1\end{array}$

$\begin{array}{llll}\text { osteomyelitis } & 1 & 0 & 1\end{array}$

Chapter 14: N00-N99 Diseases of the genitourinary system

ISK $\quad \begin{array}{llll}6 & 1 & 5\end{array}$

Nephropathy

Renal Disease

$1 \quad 0 \quad 1$

Renal Failure

$\begin{array}{lll}2 & 1 & 1\end{array}$

Chapter 15: O00-099 Pregnancy, Materal Condition and Post partum condition

\begin{tabular}{llll} 
Partus Spontan & 2 & 1 & 1 \\
\hline Chapter 16: Penitanal Condition & & & \\
IUFD & 1 & 0 & 1 \\
Birth Asphixia & 1 & 0 & 1 \\
\hline
\end{tabular}




\begin{tabular}{lccc}
\hline $\begin{array}{l}\text { Chapter 18: Sign, symtoms, } \\
\text { Abnormal Finding }\end{array}$ & & \\
Convulsion & 2 & 0 & 2 \\
anorexia & 1 & 0 & 1 \\
hypoxia & 2 & 0 & 2 \\
shock cardiogenic & 12 & 0 & 12 \\
septic shock & 45 & 0 & 45 \\
abnormality of albumin & 1 & 0 & 1 \\
asphyxia & 2 & 0 & 2 \\
sudden death & 7 & 0 & 7 \\
Senility & 5 & 0 & 5 \\
\hline
\end{tabular}

\section{PEMBAHASAN}

Berdasarkan tabel distribusi karakteristik data pasien diatas, bahwasannya pada surat kematian diketahui jenis kelamin laki-laki sebesar 73 (60,83\%) dan perempuan 46 (39,17\%), penjabaran data administratif sangat mendukung dalam pencatatan survailans kesehatan (Nichols et al., 2018). Sejalan dengan penelitian sebelumnya bahwasannya salah satu komponen dalam data demografi digunakan departemen catatan sipil untuk sesnsus kematian penduduk (Filippatos et al., 2016)(Nichols et al., 2018)

Pengukuran kualitas UCOD di RSUD Panembaan senopati dengan membagi menjadi 5 kriteria umum, Pentingnya ketepatan dalam penentuan UCOD akan berdampak terhadap pelaporan kematian kepada pihak internal maupun eksternal (Akter et al., 2015)(Jansson, 2005). Dari penelitian ini diperoleh dalam pembuatan sertifikat kematian untuk pemberian coding mengacu pada kaidah yang ditetapkan oleh WHO(World Health Organization, 2006), dengan mengisikan diagnosis yang dianggap sebagai penyebab kematian dengan menuliskan waktu kejadian dan runtutannya, namun di RSUD Panembahan Senopai Bantul hanya sebatas pengisiannya saja pada formulir ringkasan masuk dan keluar lembar kedua tanpa melengkapi waktu kejadiannya, sehingg dalam surat tersebut dalam menentukan UCOD belum berdasarkan tabel MMDS. Standarisasi yang ditetapkan oleh WHO harus dipenuhi, hal ini bertujuan ada sinkronisasi antara waktu terjadinya dan penegakan diagnosis untuk memperoleh informasi secara konprehensif dalam menentukan UCOD (Bratzler et al., 2011). Pentingnya menggunakan kaidah tersebut untuk mempermudah coder professional menentukan UCOD(Lu, Lee and Chou, 2000) (Zellweger, Junker and Bopp, 2019). Hasil UCOD tersebut tentunya dapat dijadikan sebagai data laporan kematian, dimana laporan tersebut berperan penting mendukung para pemangku kebijakan(Morano and Watkins, 2017)

Ketepatan coding oleh seorang coder tidak hanya mempermudah dalam menentukan hubungan causal atau reseleksi dalam memilih UCOD tetapi juga menggambarkan kualitas rekam medis dan laporan kematian yang dibuat (Jansson, 2005)(Morano and Watkins, 2017)

Hasil diatas pada Penggolongan diagnosis tertinggi sebagai UCOD pada kelompok Certain infectious and parasitic diseases sebanyak 10 kasus (18\%). Berkutnya kelompok Diseases of the circulatory system sebesar 8 (15\%), bahwasannya kelompok penyakit yang disebabkan oleh infeksius dapat dijadikan perhatian khusus terkait kebersihan, patient safety dan penularan penyakit dan pentingnya pencegahan (Rampatige et al., 2014)(Bhopal, 2002) (Singer, 2017). Selain penyakit menular, perhatian pemerintah saat ini adalah meningkatnya kematian dikarenakan penyakit yang tidak menular sehingga para pembuat kebijakan, pakar epidemiologi dan para pengambil keputusan harus fokus pada permasalah ini (Satman et al., 2013)(Walker, 2012)

Sebanyak 120 surat kematian yang dilaporkan, untuk ketepatan penetuan UCOD masih ada dibawah 50\% hal ini dibuktikan ketika peneliti menganalisis meggunakan tabel MMDS. Ketepatan dalam menentukan UCOD tidak hanya berdampak terhadap pelaporan kematian (Redelings, Wise and Sorvillo, 2007)(Falci et al., 2018), namun dalam penentuan tarif layanan kesehatan yang diberikan serta ketepatan pengambilan keputusan untuk pemangku kebijakan(Hazard et al., 2018)(Morano and Watkins, 2017). Pada laporan kematian diatas dikategorikan berdasarkan penggolongan diagnosis, dari hasil analisis diagnosis penyebab kematian adalah penyakit tidak menular, sehingga diperlukan perhatian khusus tidak hanya pemberi layanan kesehatan tetapi juga pada pengambil keputusan atau kebiajakan kesehatan (Mellhammar et al., 2016) (Tobergte and Curtis, 2013).

\section{SIMPULAN}

Simpulan dari penelitian ini bahwasannya di RSUD Panembahan Senopati Bantul telah membuat surat keterangan kematian bagi pasien yang meninggal disana dengan mengisikan pada formulir ringkasan masuk dan keluar pada lembar ke dua, namun belum 
mencantumkan waktu penentu diagnosis, selain itu dokter telah mengisikan diagnosis-diagnosis yang dianggap sebagai menyebab kematian namun dalam penentuan UCOD belum tepat dikarenakan coding diagnosis yang diisikan tidak tepat, sehingga berdampak pada penentuan UCOD dan belum sepenuhnya mengacu pada pedoman mortality rule yang ditetapkan oleh WHO. Dari 120 surat keterangan kematian yang dibuat sebanyak 375 kasus penyakit yang dilaporkan dikelompokkan pada diagnosis sesuai WHO sebanyak 55 kasus sebagai penyebab dasar kematian (UCOD). Penggolongan diagnosis tertinggi sebagai UCOD, pada kelompok Certain infectious and parasitic diseases sebanyak 10 diagnosis (18\%), penggolongan berdasarkan Sign, symtoms, Abnormal Finding sebanyak 9 diagnosis (16\%) dan kelompok Diseases of the circulatory system sebesar 8 (15\%). Dari laporan diagnosis sebanyak 374 tersebut yang memenuhi kategori tepat (55) dan tidak tepat (311). pengukuran kualitas UCOD yang dilaporkan, peneliti mengklasifikasikan UCOD menjadi 5 bagian diantaranya peruntutan kasus yang tidak mungkin sebesar 46 (38\%), UCOD tidak tepat 39 (33\%), Terdapat multiple kondisi yang tidak berkaitan dilaporkan dalam satubaris $15(13 \%)$, terdapat satu kondisi yang dilaporkan saja sebesar 12 (10\%). Dari hasil penilaian pada ketepatan coding diagnosis dan UCOD yang dilaporkan masih terdapat data yang tidak sesuai dengan laporan kematian di RSUD Panembahan Senopati Bantul Yogyakarta.

\section{UCAPAN TERIMA KASIH}

Kami ucapkan terima kasih kepada semua anggota peneliti Program Studi Rekam Medis dan Informasi Kesehatan Fakultas Kesehatan Universitas Jenderal Achmad Yani Yogyakarta yang memberikan kesempatan dan ijin kepada kami untuk melakukan penelitian. Terima kasih banyak kepada pihak Kementerian Riset dan Pendidikan Perguruan Tinggai (Kemenristekdikti) yang memberikan kepercayaan kepada kami dengan memberikan hibah penelitian sebagai peneliti pemula. Tak lupa kami ucapkan terima kasih kepada semua pihak bagian rekam medis dan RSUD Panembahan Senopati bantul yang mendukung jalannya penelitian ini dengan lancar

\section{DAFTAR PUSTAKA}

Akter, T. et al. (2015) 'Is there any association between parental education and child mortality? A study in a rural area of Bangladesh', Public Health. Elsevier Ltd, pp. 1-8. doi: 10.1016/j. puhe.2015.08.004.

Bhopal, R. S. (2002) Concepts of Epidemiology: First. Britain: oxford university press.

Bratzler, D. W. et al. (2011) 'An Administrative Claims Model for Profiling Hospital 30- Day Mortality Rates for Pneumonia Patients', 6(4). doi: 10.1371/journal.pone.0017401.

Dinkes Yogyakarta (2016) Profil Kesehatan Daerah Istimewa Yogyakarta Tahun 2016Yogyakarta, Dinas Kesehatan.

Falci, L. et al. (2018) 'Practice of Epidemiology Examination of Cause-of-Death Data Quality Among New York City Deaths Due to Cancer, Pneumonia, or Diabetes From 2010 to 2014', 187(1), pp. 144-152. doi: 10.1093/ aje/kwx207.

Filippatos, G. et al. (2016) 'The quality of death certification practice in Greece', Hippokratia, 20(1), pp. 19-25.

Hazard, R. H. et al. (2018) 'Comparing tariff and medical assistant assigned causes of death from verbal autopsy interviews in Matlab , Bangladesh : implications for a health and demographic surveillance system'. Population Health Metrics, (June). doi: 10.1186/s12963018-0169-1.

Hersh, W. R. (2016) 'Adding Value to the Electronic Health Record Through Secondary Use of Data for Quality Assurance, Research, and Surveillance', American Journal of Manage care, 13(6), pp. 277-278.

IFHIMA (2012) Education Module for Health Record Practice Module $5 b$ - Disease \& Procedure Classification and Indexing.

Jansson, B. (2005) 'Coding errors and underestimation of fall injury mortality [2] (multiple letters)', American Journal of Public Health, 95(8), pp. 1305-1306. doi: 10.2105/AJPH.2005.067553. 
John Hopkins (2006) 'Mortality and Morbidity Data Sources for Measuring Mortality’.

Lu, T. H., Lee, M. C. and Chou, M. C. (2000) 'Accuracy of cause-of-death coding in Taiwan: Types of miscoding and effects on mortality statistics', International Journal of Epidemiology, 29(2), pp. 336-343. doi: 10.1093/ije/29.2.336.

Mellhammar, L. et al. (2016) 'Sepsis Incidence : A Population-Based Study’. doi: 10.1093/ofid/ ofw207.

Morano, L. H. and Watkins, S. (2017) 'Evaluation of diagnostic codes in morbidity and mortality data sources for heat-related illness surveillance', Public Health Reports, 132(3), pp. 326-335. doi: 10.1177/0033354917699826.

Nichols, E. K. et al. (2018) 'The WHO 2016 verbal autopsy instrument : An international standard suitable for automated analysis by InterVA, InSilicoVA, and Tariff 2 . 0', pp. 1-9.

Rampatige, R. et al. (2014) 'Systematic reviews Systematic review of statistics on causes of deaths in hospitals : strengthening the evidence for policy-makers', (January 2015). doi: 10.2471/BLT.14.137935.

Redelings, M. D., Wise, M. and Sorvillo, F. (2007) 'Practice of Epidemiology Using Multiple Cause-of-Death Data to Investigate Associations and Causality between Conditions Listed on the Death Certificate', 166(1), pp. 104-108. doi: 10.1093/aje/ kwm037.
Satman, I. et al. (2013) 'Twelve-year trends in the prevalence and risk factors of diabetes and prediabetes in Turkish adults', pp. 169-180. doi: 10.1007/s10654-013-9771-5.

Scott, J. T. et al. (2005) 'Kaiser Permanente's experience of implementing an electronic medical record: a qualitative study.', $B M J$ (Clinical research ed.), 331(7528), pp. 1313-6. doi: 10.1136/bmj.38638.497477.68.

Singer (2017) Improving the prevention, diagnosis and clinical management of sepsis. WHO. doi: 10.1001/jama.2016.0287.1.

Tobergte, D. R. and Curtis, S. (2013) Strengthening civil registration and vital statistics for births, deaths and causes of death, Who. doi:10.1017/ CBO9781107415324.004.

Walker, P. J. R. (2012) 'Mortality, Morbidity and Health', pp. 1-46. Available at: www.ssc. wisc.edu/ walker/wp/wpcontent/uploads/.../ E623MortLec.pdf.

World Health Organization (2006) Medical Records Manual : A Guide for Developing Countries. Geneva.

Zellweger, U., Junker, C. and Bopp, M. (2019) 'Cause of death coding in Switzerland: evaluation based on a nationwide individual linkage of mortality and hospital in-patient records'. Population Health Metrics, 2, pp. $1-15$. 